\title{
Lymphoid Involvement of Cerebrospinal Fluid in Lyme Disease
}

\author{
Floriane Lefeuve and Lucile Baseggio* \\ Laboratoire d'hématologie biologique, France
}

*Corresponding author: Lucile Baseggio, Laboratoire d'hématologie biologique, Groupement Hospitalier Lyon-Sud/Hospices Civils de Lyon, 69495 PIERRE BENITE Cedex, France

\begin{tabular}{|c|c|}
\hline ARTICLE INFO & ABSTRACT \\
\hline Received: 㓞 March 20, 2019 & \multirow{2}{*}{$\begin{array}{l}\text { After typical rash (erythema migrans), neurological involvement is the most common } \\
\text { clinical manifestation in Lyme disease. The cerebrospinal fluid (CSF) analysis may help in } \\
\text { any diagnostic doubt characterized by CSF pleocytosis (lymphoïd and plasma cells) and } \\
\text { borrelia-specific antibodies produced intathecally. }\end{array}$} \\
\hline Published: 豐 March 27, 2019 & \\
\hline
\end{tabular}

\section{Introduction}

A 62-year-old man presented with a back pain radiating to right thigh, severe asthenia and no fever. Serum $C$ protein and erythrocyte sedimentation rate were normal. Two months later given tetraparesis manifestation, a MR scan of spine has been realized and displayed high-density signal extending between T11 to L1. The MR scan of brain was normal. Infectious mononucleosis screen, syphilis, HIV, hepatitis B and C serology were negative. Cerebrospinal fluid (CSF) revealed hypercellular specimen (white blood cells $=630 / \mu \mathrm{L}$, red blood cells $=10 / \mu \mathrm{L}$ ). The protein concentration was $2.1 \mathrm{~g} / \mathrm{L}$ and glucose $3.2 \mathrm{mmol} / \mathrm{L}$ (normal paired plasma glucose). The cytological analysis of CSF (cytocentrifuge preparation, magnification x60, May-Grünwald Giemsa staining, Figure 1A-1C showed polymorphous lymphoïd population including small lymphocytes, granular lymphocytes, large immunoblasts (arrow) and plasma cells (asterisk).
Flow cytometry (FCM) immunophenotyping of CSF (Figure 1D) identified mainly small T-cells (84\%) associated to polytypic B-cells $(10 \%)$ including large and small cells, and polytypic plasma cells (4\%). Morphology associatied to immunologic profile argue to CSF involvemennt by activated lymphoïd population. The patient only remembered untreated skin lesions on abdomen 10 weeks before. The Borrelia enzyme immunoassy result was found to be reactive and confirmed with positive immunoblot to IgG and IgM. The CSF also contained antibodies to Borrelia and the Borrelia-specific CSF to serum IgG antibody index was at 8.1 (normal range $<1.3$ ). The patient was therefore diagnosed with Lyme neuroborreliose and treated with intravenous ceftriaxone, which resulted in an almost complete recovery. 

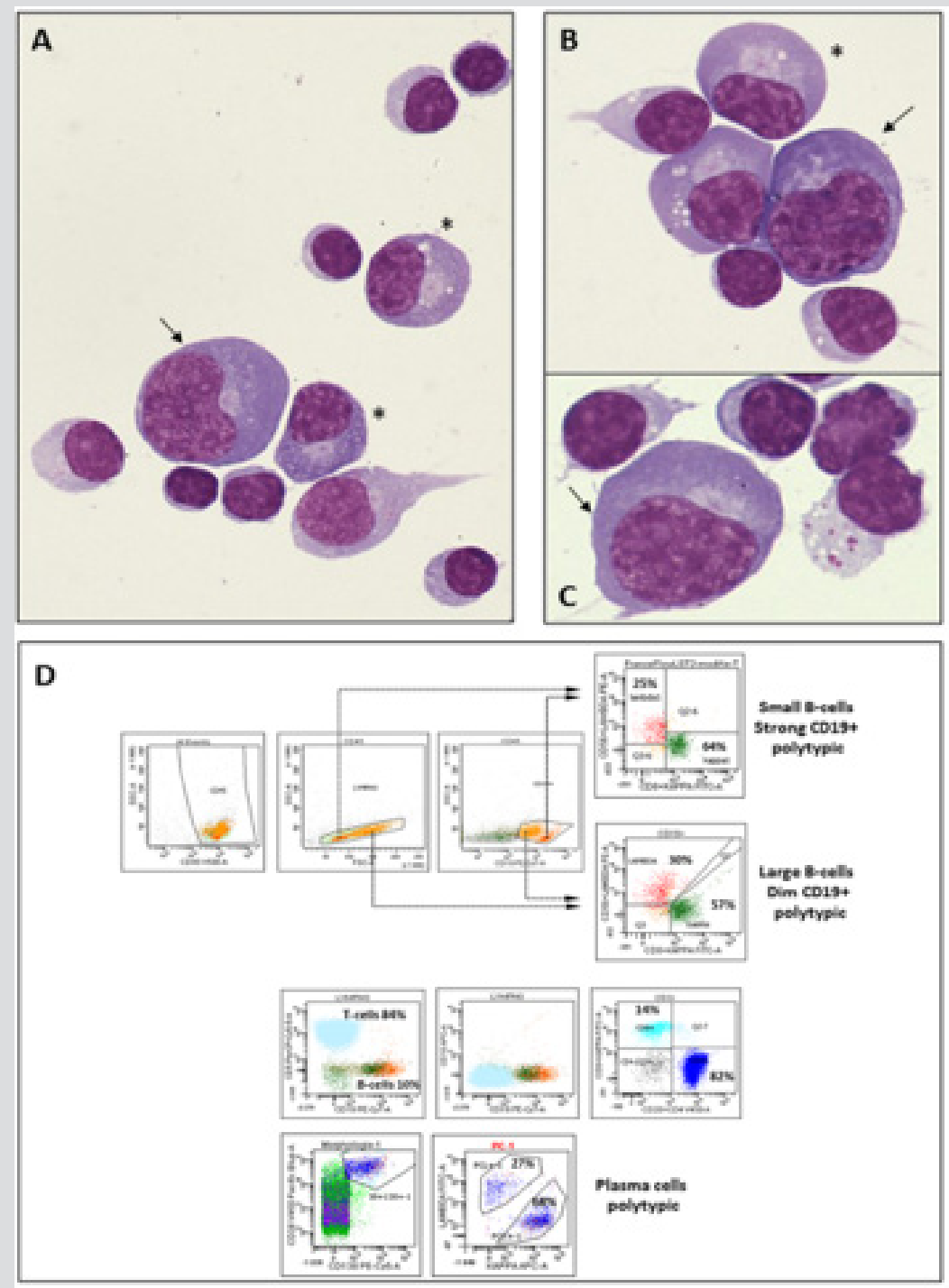

Figure 1: Cerebrospinal fluid (CSF) (cytocentrifuge preparation, magnification x60, May-Grünwald Giemsa staining, Fig A-C): Small lymphoid cells (scanty cytoplasm and regular nuclear), granular lymphocytes (abundant and pale cytoplasm with azurophilic granules), immunoblasts (large cells with abundant and basophilic cytoplasm; arrow) and plasma cells (eccentric nuclei with clumped chromatin and basophilic cytoplasm; asterisk). Immunophenotype by multiparameter flow cytometry (FCM) was realized on CSF. Data were acquired on a BD FACSCanto II cytometer and analyzed with BD FACS DIVA version 8.0.1 software (*Becton Dickinson, San Jose, CA, USA). A first panel of 10 antibodies in one tube was used to identify T- and B-cells : CD3 (clone SK7,15-18*, APC-H7), CD5 (clone L17F12*, PerCP Cy5.5), CD4 (clone RPA-T4*, V450), CD8 (RPA-T8*, FITC), CD45 (clone HI30*, V500), CD20 (clone L27-9*, V450), CD19 (clone J3-119**, PE Cy7), CD10 (clone HI10a3*, APC), CD56 (clone NCAM 16,2*, PE) and kappa/lambda (**, FITC/PE) (** Beckman-Coulter, Hialeah, FL, USA, ***Dako, Carpinteria, CA). A second panel was used to identify plasma cells (including CD38 [clone HB7*, V450], CD138 [Syndecan-1**, PC5]).

\section{Conclusion}

In conclusion, this case illustrates CNS involvement in neuroborreliosis that will develop in less of $5 \%$ of untreated erythema migrans, and usually 4-6 weeks after tick exposure [1]. Only $25 \%$ of patients with neuroborreliosis recall a tick bite and about $50 \%$ report a localized skin reaction so the absence of a history of tick bite or rash does not exclude the diagnosis. Although the analysis of CSF is not recommended in all patients, in any diagnostic doubt it will be usefulness with characteristically
CSF pleocytosis (lymphoïd and plasma cells) and borrelia-specific antibodies produced intathecally $[2,3]$.

\section{References}

1. Hansen K, Lebech AM (1992) The clinical and epidemiological profile of Lyme neuroborreliosis in Denmark 1985-1990. A prospective study of 187 patients with Borrelia burgdorferi specific intrathecal antibody production. Brain 115(2): 399-423.

2. Krüger H, Kohlhepp W, König S (1990) Follow-up of antibiotically treated and untreated neuroborreliosis. Acta Neurol Scand 82(1): 59-67.

3. (2018) NICE, Lyme disease overview. 


\section{ISSN: 2574-1241}

DOI: 10.26717/BJSTR.2019.16.002854

Lucile Baseggio. Biomed J Sci \& Tech Res

cC (P) This work is licensed under Creative

Submission Link: https://biomedres.us/submit-manuscript.php

$\begin{array}{ll}\text { BIOMEDICAL } & \text { Assets of Publishing with us } \\ \text { RESEARCHES } & \text { Global archiving of articles } \\ & \text { - Immediate, unrestricted online access } \\ & \text { - Rigorous Peer Review Process } \\ \end{array}$

